\title{
Determining the Factors That Influence the Intention to Purchase Luxury Fashion Brands of Young Consumers
}

\author{
Genç Tüketicilerin Lüks Moda Markalarını Satın Alma Niyetini Etkileyen \\ Faktörlerin Belirlenmesi
}

Sevtap ÜNAL ${ }^{1}$

Elif DENIZ²

Nisa AKIN $^{3}$ https://orcid.org/0000-0002-3227-0756

https://orcid.org/0000-0002-5849-1629

https://orcid.org/0000-0001-6873-5757

\begin{abstract}
The purpose of this study is to determine the factors thatinfluencethepurchase ofluxuryfashionbrands by young consumers. With the help of a comprehensive literature review; status consumption, self-concept clarity, need for uniqueness, social consumption motivations, attitude toward luxury brands as input factors and purchase intention as output factor are discussed. The moderating effect of peer pressure is also investigated. Based on the research model and developed hypotheses, a quantitative method was used in the study. 400 questionnaires were used to test research hypotheses. A structural equation modeling running SPSS 20 and AMOS was used in testing research hypothesis. Findings show that while status consumption and creative choice (one dimension of the uniqueness) do influence social consumption motives, self-concept clarity, unpopular choice and avoidance of similarity do not influence social consumption motives and purchasing intentions. Peer pressure has a moderating effect on the relationship between selfconcept clarity and social consumption motives. Positive attitudes increase the intention to purchase luxury brands while social consumption motivations affect the attitude toward a luxury brand.
\end{abstract}

Keywords: Luxury brands, young consumers, social consumption motivations, peer pressure, purchase intention

\section{ÖZET}

Bu çalışmanın amacı genç tüketicilerin lüks markaları satın almasına etki eden faktörleri tanımlamaktır. Kapsamlı bir literatür taramasıyla beraber; girdi faktörler olarak statü tüketimi, benlik algılaması netliği, benzersizlik ihtiyacı, sosyal tüketim motivasyonları, lüks markalara karşı tavır ele alınırken, satın alma niyeti çıktı faktör olarak irdelenmiştir. Akran baskısının moderatör etkisi de ayrıca incelenmiştir. Araştırmanın modeli ve geliştirilen hipotezlere dayanarak, çalışmada kantitatif bir yöntem kullanılmıştır. 400 anket araştırma hipotezlerini test etmek üzere kullanılmıştır. Araştırma hipotezlerini test ederken SPSS 20 ve AMOS kullanılarak yapısal eşitlik analizinden yararlanılmıştır. Bulgulara göre, statü tüketimi ve yaratıcı seçim (benzersizliğin bir boyutu) sosyal tüketim motivasyonlarını etkilerken benlik algılaması netliği, popüler olmayan tercih ve benzerliği önleme sosyal tüketim motivasyonlarını ve satın alma niyetini etkilememektedir. Benlik algılaması netliği ve sosyal tüketim motivasyonları arası ilişkide akran baskısı moderatör bir faktördür. Sosyal tüketim motivasyonları lüks bir markaya karşı olan tutumu etkilerken pozitif tutumlar lüks markayı satın alma niyetini arttırmaktadır.

Anahtar Kelimeler: Lüks markalar, genç tüketiciler, sosyal tüketim motivasyonları, akran baskısı, satın alma niyeti

'Prof. Dr.,İzmir Kâtip Çelebi Üniversitesi, İktisadi ve İdari Bilimler Fakültesi, İşletme Bölümü, İzmir, Türkiye, sevtap.unal@ikc.edu.tr,

${ }^{2}$ Dr. Öğr. Üyesi, İzmir Kâtip Çelebi Üniversitesi, İktisadi ve İdari Bilimler Fakültesi, İşletme Bölümü, İzmir, Türkiye, elif.deniz@ikc.edu.tr

${ }^{3}$ Araş. Gör., İzmir Kâtip Çelebi Üniversitesi, İktisadi ve İdari Bilimler Fakültesi, İşletme Bölümü, İzmir, Türkiye, 


\section{INTRODUCTION}

It is obvious that consumption is defined not only as a purchase of material objects which is a simple, direct utilitarian use but also as purchases of objects which convey meaning and which the consumer will use to show who they intend to be (Bocock, 1997: 59). It can be said that this definition includes especially luxury consumption, when luxury goods are expressed as products purchased by consumers because of their symbolic meaning. It is impossible to speak of the existence of a definition accepted by the theorists alike in the definition of luxury and luxury products. However, in general, it is possible to think in terms of prestige and brand image and products that are attracted to consumers, which can be easily distinguished from other products with a relatively high unit price, in the luxury product category. However, the change from one consumer to another in the distinguishing features that fill the content of the definition of luxury shows how subjective the approach is to include a product in the luxury product category.

Today, when consumption is expressed by symbols and life is seen as an experience of consumption, images and symbols are important as the elements of the consumer's cultural identity (Willis, 1991: 131). Indeed, Veblen's concept of fictive consumption also attempts to explain the type of new consumer that leads to symbols and images in creating his/her identity (Veblen, 2005: 67, 101). In this consumption approach, which is based on stating, status and inaccessibility, the individual is not only a utilitarian consumer that solves his/ her physical needs; at the same time, it is accepted as a hedonic consumer trying to fulfill his/her social and cultural needs (Odabaşı, 2014: 65). According to Sombart, another thinker who advocates similar views with Veblen, it expresses any kind of consumption action that the individual has made except for the removal of the basic necessities (Sombart, 1998: 153). Therefore, in the promotion of luxury goods, it is highlighted that what the product means, not what its functional features. This is because the image and status relation for the consumer with all kinds of products/brands that reveal them represent the social class, status, and prestige. This need is often sought to be satisfied with luxurious consumer goods with status symbols (Odabaşı, 1999: 115). The concept of luxury, which is found in all of these approaches towards symbolic, emotional and pleasure consuming, is often used in the literature with concepts of difference, uniqueness and inaccessibility (Belk, 2001; Miremadi et al., 2011). Consumers who want to separate themselves from other members of the society and want to create a different individual image from the others (Catry, 2003: 11) need status consumption in order to position themselves as belonging to a culture and community, and associate luxury goods with symbolic and spiritual satisfaction instead of benefit category (Tenekecioğlu, 2005, Tığlı and Akyazgan, 2003) as a means of producing social status. All these concepts and approaches show that; individuals today are trying to differentiate themselves from others by means of status, fashion and elegancy. The phenomenon of luxury consumption, which manifests itself in such images through fashion and status, objects itself in the form of images, signs and consumable abstract showings. Consumers regard themselves as a rare group of people who can buy luxury goods and belong to a group.

Especially when interpreted from the perspective of young consumers, luxury products can be defined as the tools consumers use to express themselves, build self-esteem and provide prestige. Indeed, this study was undertaken to find out what kind of influence the young people have on purchasing intentions that affect the luxury consumption behavior. In recent years, research on consumer behaviors, how young people behave as consumers, and how they have changed as an adult consumer are important for both business and marketing practitioners (Eskiler et al., 2016: 710). With this in mind, it has been tried to put in particular how the university student youths were influenced by the luxury consumption behavior, their income and spending, and the socio-economic status of their parents in terms of education levels. In the consumption of luxury products, consumers are not only effected by demographics, social and economic characteristics of themselves; at the same time, they are also influenced by their impressions of the consumption of the groups they want to feel that they belong in a place. Young people who want to identify themselves in a group or who want to prove their existence within a certain group seem to be leading to the consumption of luxury goods simply because of the psychological pressure of their peers (Alvandi et al., 2013; Gil et al., 2017 and Srinivasan et al., 2014). This also shows that luxury consumption is not merely monopolizing the rich and affluent segment of the society, but less affluent people and young people who are interested in lucidity also try to buy luxury items with peer pressure to just enjoy, to belong to a particular group/class and to be accepted by their friends. 
Unlike wealthy customers who are seen as traditional luxury customers, young consumers who can be considered less wealthy are turning to clothing products as the fastest and most readily available manifestation of luxury consumption. For this reason, the principal focal point of the study is about the luxury perception and its determinants that young people have developed the clothing industry products/ brands. Clothing fashion, in which the visual emphasis of individual identity is most intense and distinct, is one of the most frequently consumed areas of luxury consumption behavior. Compared to other products, clothing products, as a demonstration object, allow young and less affluent consumers to capture the pleasures of luxury consumption with comparatively fewer expenses than wealthy consumers. For this reason, in the study, the university students' attitudes towards luxury products and the elements that led them to buy luxurious products were tried to be described in terms of clothing fashion.

In this study, considering the promising future of global luxury consumption market, it is aimed to determine the factors affecting the buying behaviors of the luxury fashion brand of young fashion consumers. The impact of the status consumption, self-concept clarity, need for uniqueness, social consumption motives and attitudes towards luxury brands on purchase intentions of young consumers and the market in Turkey are wanted to test in the study. The peer pressure is also evaluated as a moderating variable. In the first part of the study, theoretical background and hypothesis development are discussed. After giving details about the research methodology findings, the final section discusses the results and discussions in order to contribute in the literature and give some remarks to the actors in the sector.

\section{LITERATURE REVIEW AND HYPOTHESIS}

\subsection{Definition of Luxury and Luxury Consumption}

Luxury used to be defined quite differently throughout the human history. In Latin, the term luxury means "extravagantness, going rampant, dramatizing, profligacy" but in French, it means "voluptuousness, sinfulness". In the 17th century, the meaning of luxury was transformed into escaping from the facts, a kind of cure, common and upgraded motives. However, in the modern world, the meaning of luxury goes beyond the basic needs and turns into a kind of flashy consumption (Berthon et al., 2009). Luxury is a status that is unnecessary in terms of basic needs, but something gives pleasure, happiness, and self-confidence and creates the perception of easiness (Hauck and Stanforth, 2007).

Luxury and fashion are closely connected in the modern economy. The global fashion industry would be the seventh largest economy in the world if the countries were ranked with the GDP (The State of Fashion, 2017). In this fashionable modern world, luxury apparels are perceived as a necessity (The State of Fashion, 2017; Business Wire, 2017a). According to the "Global Luxury Apparels Market (2017-2023)" report, the global luxury apparel market has shown a moderate level of growth over the last five years among all global textile sectors and apparel industry. In 2016, sales of luxury apparel, beauty products, accessories, and jewelry were about $\$ 280$ billion which is expected to grow by 2 to 4 percent in 2017. The total revenue of the global luxury apparel market is expected to reach $\$ 77.8$ billion, marking a 3.3\% growth in 2017 (Business Wire, 2017a). The total revenue of the global luxury apparel market is expected to reach $\$ 77.8$ billion, marking a 3.3\% growth in 2017. China, closely followed by Japan and India, is still the largest market for global luxury products, also is expected to grow by 6 to 8 percent and Europe sales are expected to increase by 7 to 9 percent (Barry, 2017; Business Wire, 2017b; Europlat, 2017; Deloitte, 2017).

According to Dikmen, luxury should be a functional addiction as a reward since the consumers of luxury seem to be materialistic, choosy, eager to pay for it, seeking for psychological gains (Dikmen, 2008). Catry (2003) argues that consumers of luxury show tendency to perceive themselves more superior and distanced than the other consumers and they create emotional reactions towards luxury products with hedonic demands. They also tend to purchase to prove their status and images in their social surroundings (Tığlı and Akyazgan, 2003). The meaning of a luxury product can be defined through social and individual values and includes rareness, prestige, and glitziness, symbolic and emotional needs (Hauck and Stanforth, 2007).

On the other hand, Rambourg brings a new perspective to the luxury consumption with a brand pyramid that shows how to get ultra-luxury brands like Leviev and Graff diamonds from a daily luxury brands like Starbucks. He states that a luxury product costs up to 100 dollars can be defined as everyday luxury and any other costs up to 300 dollars can 
be defined as affordable luxury. The consumers of everyday and affordable luxury are still rising in the market due to the rising incomes (Willett, 2015). From this point of view, Turkish luxury consumption market is highly promising. Based on Deloitte's report (2017), it is stated that in 2018 Turkish luxury consumption market will be worth 7 billion Turkish liras due to the fact that zeitgeist refers to 'time of vanity' in Turkey and these products are perceived as status symbols. Also; middle-income group's demand for accessible luxury rises and working woman consumers are much more mindful of luxury products. Using social media and e-commerce incite luxury consuming trends in Turkey. According to Bain \& Company's Global Luxury Consumption Report (2016), by the time 2020, 50 million new consumers who belong to $X$ and $Y$ generation will be joined to the luxury consumption market.

\subsection{Status Consumption}

Luxury commodities, which are regarded as determinants of quality and status, have become more affordable and easily accessible in recent years. By purchasing luxury goods and brands, consumers look for social statuses in different forms and try to improve their social position through such consumption. According to Eastman et al. (1999), status consumption is seen as a motivation process in which individuals struggle to improve their social position by the consumption of consumer goods that give status and symbolize the individual to both individuals and people in the periphery. Although status consumption and conspicuous consumption are discussed in some studies (Açıkalın and Erdoğan, 2004); O'Cass and McEwen (2005) test and demonstrate that both consumption concepts have different structures.

Eastman et al. (1999) developed a scale to measure status consumption by using it an individual difference variable in which measure has been shown that what precautions are related to similar structures such as income, social class and materialism are different from each other. Also, Kilsheimer (1993) developed a scale by using social and conspicuous consumption as the same constructs. In addition, some studies about fashion and luxury apparel with different perspectives also indicate that the relationship between status consumption and religiosity (O'Cass et al., 2013), the association between economic perceptions and the consumption motive of luxury consumers (Bock et al., 2014) as well. The results suggest that there is an inverse relationship between consumption of status and religiosity, and that consumers who perceive themselves financially better are more motivated for status consumption.

Based on the literature, it has been found that younger consumers spend more on branded products, including status products (Goldsmith and Clark, 2012; Eastman and Liu, 2012). As clothing is defined as a product category that is accessible to everyone, for younger, it becomes the easiest way of broadcasting one's self-image to others with status aspirations in social surroundings (Millan and Mittal, 2017). It also means that attitudes about luxury consumption may be related to the symbolic meaning of one's social position and identity (Eastman and Eastman, 2011). With the help of social consumption motives, consumers become more aware of social cues about luxury consumption. Therefore, building on these discussions, $\mathrm{H} 1$ and $\mathrm{H} 2$ are stated as;

H1. The level of status consumption positively influences the level of social consumption motivation.

H2. The level of status consumption positively influences the level of attitudes towards luxury brands.

\subsection{Self-Concept Clarity}

The beliefs that an individual has about his qualities and how he evaluates these qualities in himself can be defined by the concept of self. As a basic research topic in psychology and sociology (Alvandi et al., 2013), the concept of self is a very complex structure, personal traits and characteristics like personality and self-perceptions. Some studies reveal that; adolescence is an important time in the development of the concept of self (Fullwood et al., 2016), the higher subjective concept of self affects how people seek and interpret information in their environment (Guerrettaz and Arkin, 2016), individuals who are higher on the social-class index exhibit a clearer self-concept regardless of their age, gender, and living conditions ( $\mathrm{Na}$ et al., 2016). However, SCC studies lack in marketing literature especially focusing on luxury or clothing. Distinguishing SCC from self-esteem, Mittal (2015) investigates SCC and its role in consumer behavior and reveals that SCC makes consumers less sensitive to interpersonal effects, inhibits materialism and consumer use of shopping as an escape, reduces consumer tendency to search products as identity pillars. Sonejia et al. (2015) examine the clarity of self-concept and the meaning of fame show that high-SCC consumers are more influenced by an ad featuring a celebrity high in meaning. Noguti and Bokeyar (2011) indicate that low 
self-concept clarity tend to engage consumers with higher fantasy-shopping tendencies.

According to some studies focusing luxury and teenagers; to investigate the influence of self in the attitudes towards luxury brands among young people in Iran, Alvandi et al. (2013) found that there was a negative relationship between self-concept clarity and social consumption motivation, and that social consumption motives influenced the positive effect of luxury branding. Campbell et al. (1996) who studied personality correlations and cultural boundaries developed an SCC scale in which SCC was found a relatively stable trait that is reliably and validly measured.

Clearly and confidently defining the self concept of the person is possible by having a strong sense of self. A person who has a well-developed concept of self is found to be less affected by external influences, have better mental skills, positive self-talk, ability to handle stress and high self-esteem (Gil et al., 2017). What comes to mind when a person thinks about him/ herself is self-concept, and it is also about perceiving the self. Experiences with the environment and the reinforcements coming from this environment and the others form the perceptions. Especially the self-concept can help to understand how teenagers express his or her unique individual self to the environment while consuming goods or services (Gil et al., 2012; Alvandi et al., 2013).

H3. The level of self-concept clarity negatively influences the level of social consumption motivation.

\subsection{Need for Uniqueness}

Consumption as a tool that individuals use when building their identity in society helps to produce the identity while consuming. Thus, luxury brands are one of the important tools for individuals to express themselves. While buying brands to create a unique identity and to feel different from others, they are also exposed to various marketing stimuli of the brands. Consumers' need for uniqueness is an important factor affecting the use of luxury brands in order to improve and enhance the individual's personal and social identity (Tian et al., 2001). Indeed, studies have shown that the desire for uniqueness-scarce products has a stimulating effect on behaviors such as the delicacy of product personalization and the preference for unique and innovative purchasing experiences (Lynn and Harris, 1997; Vigneron and Johnson, 1999).
The uniqueness theory that affects the motivations of social consumption for consumers who want to emphasize the features that differentiate themselves from others shows itself to three types of consumers: avoidance of unpopular selection vs. harmony and similarity (Tian et al., 2001; Manikandan and Rajamohan, 2014). Especially for young consumers it is seen that luxury brand and product perceptions are related to the desire for uniqueness and that they have developed intention to buy to avoid similarities with others as social consumption motivation (Amaldoss and Jain, 2005; Ruvio, 2008; Miremadi et al., 2011; Kastanakis and Balabanis, 2014). The desire for uniqueness is theories that focus on the perceptions of individuals, and the products and brands to be purchased are seen as a symbol of the uniqueness of the persons (Boujbel and d'Astous, 2015). This leads young people who are in pursuit of a relative difference to opt for luxury products and brands in order to improve their own image and social image. This need to avoid similarity leads people to move away from others and at the same time pushes them to make choices that are popular. This is especially motivated by the luxury brands that develop fashion products to emphasize different styles. Because consumers seek rare products and brands to reach diversity and uniqueness, who want to avoid similarity.

Some consumers, who are different from mass consumers, are found to be in a desire to show themselves belong to higher income classes (Belk, 2001). One of the most important factors behind the luxury brands' passion consumers perceive as unique is the desire of individuals to feel special and privileged in the society. In the field of marketing, need for uniqueness and luxury phenomenon are often used together, and these concepts are associated with features such as creativity, innovation, quality, rarity and privilege (Belk, 2001; Kapferer, 1998). Hence using luxury brands to satisfy the need of feeling unique can be held with social consumption motivations of the consumers.

H4. The level of need for uniqueness positively influences the level of social consumption motivation.

$\mathrm{H} 4 \mathrm{a}$. As a dimension of the need for uniqueness, the level of creative choice positively influences the level of social consumption motivation.

H4b. As a dimension of the need for uniqueness, the level of unpopular choice positively influences the level of social consumption motivation. 
H4c. As a dimension of the need for uniqueness, the level of avoidance of similarity positively influences the level of social consumption motivation.

\subsection{Social Consumption Motivation}

While studying younger consumers' consumption-related perceptions, socialization theory is commonly used by researchers (Martin and Turley, 2004). According to Moschis's (1981) social consumption motivation construct, if an individual has a higher social consumption motivation, he or she should adapt to social meanings in purchasing products and brands. Also, it is stated that social consumption motivation is much more than impression management by including elements of social influence and conformity. Latest researches handle social consumption motivation investigate how consumers are coming from a lower social class turn into frequent luxury goods shoppers to be a part of the elite society or climb up the social ladder, gain social approval, enhance their social position through the individual and surrounding others (Vel et al., 2011).

Young consumers are open to products, services, and brands that enable them to express themselves in a social environment as a symbol of their lifestyle. Their desire for prestige and status also causes not only concrete benefits to their products/brands but also abstract meanings. From the perspective of consumer socialization, young consumers view status consumption as a form of social acceptance and self-expression (Bakewell and Mitchell, 2003). This is especially seen as a way of showing wealth and purchasing power in demanding luxury products and brands ( $\mathrm{O}^{\prime}$ Cass ve Frost, 2002). Not only in show times but in the symbolic sense, luxury products and branding tend to express their social position, especially through the use/consumption of status for young consumers (Eastman et al., 1999).

The status consumption concept as a factor influencing social consumption motivations and luxury product purchasing comes to the forefront in the studies of youth and status factors ( $\mathrm{O}^{\prime}$ Curry and Strahilevitz, 2001; Phau and Cheong, 2009; Eastman and Liu, 2012; O'Cass and Siahtiri, 2013). Besides communicating with others, covered by the hedonic motivations, social motivations are associated with the behaviors of seeking prestige, status, social benefits and attracting the attention of others' (Bilge, 2015). In the development of the self-motivated social consumption of young people, increasing with age and maturity plays a critical role and may depend on the self-concept clarity (Gil et al., 2012).

H5. The level of social consumption motives positively influences the level of attitudes towards luxury brands.

\subsection{Attitude toward Luxury Product}

To understand the factors leading consumers to buy luxury brands become increasingly important for both managers and researchers (Tynan et al., 2010; Wiedmann et al., 2007). Especially recent structural and cultural changes in the market let the availability of luxury more in terms of geographical access and affordable prices for the consumers. Consumers who are sensitive to the emotional rewards of self-reward, high quality of the product, need to belong a higher social class or richer mass are also seemed to be buying more luxurious products for different reasons (Truong et al., 2009). While the level of a brand's potential to create different feelings for consumers is a motivate factor; the overall intent of the consumers' beliefs, emotions, intentions of purchase, and the general evaluation of the luxury phenomenon can also be other motivations to buy a luxury product (Solomon et al., 2002).

In studies investigating how social consumption motives affect youngsters' attitudes towards luxury brands and purchasing behavior, it has been shown that self-concept influences social consumption motivations and influences attitudes toward luxury brands (Grubb and Grathwohl, 1967; Shavelson et al., 1976; Campbell et al., 1996; Kernis et al., 2000; Kavak et al., 2009; Gil et al., 2012; Alvandi et al., 2013). As a matter of fact, it is seen that, in addition to material gains in young consumers, personal liking and social acceptance also influence attitudes toward luxury brands within the context of consumer socialization (Makgosa, 2010; Akturan et al., 2011; Rhee and Johnson, 2012a; Rhee and Johnson, 2012b). For this reason, the concepts of social environment and peer pressure that we have defined as reference groups as much as the self-concept have been modeled in studies dealing with the relationship between self-centeredness and social consumption motivations.

The need to describe and accept themselves with the self's qualities, along with the individual's self, is one of the factors that affect his buying behavior. It has also been shown that communication with peers influences the relationship between self-concept clarity and social consumption motivations (Moschis and Churchill, 1978; Bush et al., 1999; Gregorio and Sung, 2010). For teenagers, consumption is a kind of self-exp- 
ression. In other words, it is not expected that young people, as individuals with low self-concept, will shape their behavior separately from the social context. For this reason, it is necessary to ignore the influence of peer pressure on the self-concept of self-esteem and motivation of social consumption as an element that may affect young people's decision-making processes for luxury products and brands.

In the case of luxury products, the desire for purchasing is even stronger than expected. There are various psychological and physical factors affecting consumers in purchasing luxury products or brands. Consumers buy luxurious brands to symbolize a specific consumption culture or to reveal belonging to a particular social class to make sense of their images and to meet their psychological needs. However, it is emphasized that people can develop positive or negative emotions against the luxury products. While the attitudes of the wealthy people on the concept of luxury are positive, the others who are less related to the luxury phenomenon are able to show mixed attitudes towards the luxury products (Stegemann et al., 2007). Hence, it can be said that different attitudes cause different effects on consumers' luxury brand purchase intentions.

H6. The level of attitude toward luxury brands positively affects the level of purchase intention.

\subsection{The Moderating Effect of Peer Pressure}

Especially during adolescence period, youngers highly value the sense of belonging to a peer group. According to Brown et al. (1986), if a younger feel him or herself pressured by the other group members to do certain things and find him or herself experiencing doing those particular things, peer pressure arises. Peer pressure is about feeling pressured to act or think in certain ways among youngers or the correlated behaviors among them (Santor et al., 2000). It also leads to consumption motivations like buying and using some specific products or brands to achieve the support of other peer group members and to enhance their image among their peers by sharing info about consumption (Gil et al., 2017; Srinivasan et al., 2014).

Based on the studies exploring the peer pressure effect, Timperio et al. (2016) argues that young consumers are different compared to others in term of perceiving luxury and the meaning and the value of luxury can be perceived through peer reference group interaction. Shukla (2012) and Schade et al. (2016) suggests that customers tend to act in such a way as to please their peers and try to engage themselves with luxury brands for gaining approval. Martin (2009), Moschis and Churchill (1978) and Gentina et al. (2016) find that compared to older, youngers are more likely to rely on their peers for purchasing-related information, are heavily influenced by peers in the adoption of attitudes toward luxury brands and peer communication about consumption develops materialistic values of youngers. Also they reveal their motivations and behavior about consumption compare their thinking about which is desirable and undesirable and adopt group norms within a peer group, as a normative reference group (Makgosa and Mohube, 2007).

H7. Peer pressure moderates the relationship between self-concept clarity and social consumption motivation.

Based on the theoretical background and developed hypotheses, the model of the research can be seen in Figure 1.

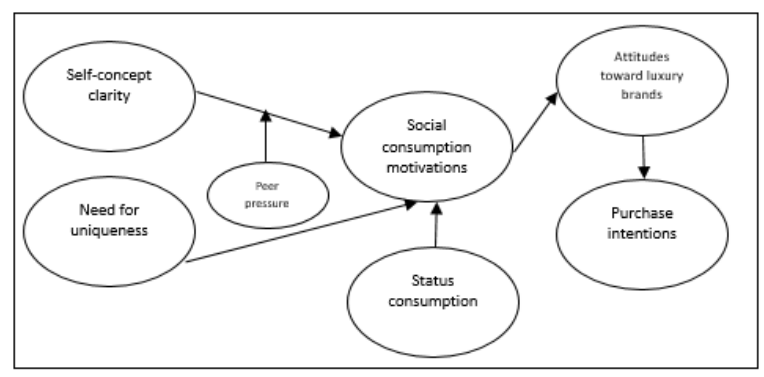

Figure 1: The Model of the Research

\section{RESEARCH DESIGN}

\subsection{Sample and Data Collection}

The purpose of this study is to determine the factors that influence the luxury fashion brand purchasing of young consumers. Based on this purpose; to test status consumption, self-concept clarity, uniqueness, and social consumption motives' effect on the attitudes towards luxury brands and then purchase intention is aimed. In addition, peer pressure moderating effect on the relationship between self-concept clarity and social motivation motives is wanted to test.

The data was collected by using a paper-based self-administered questionnaire targeting the university students who belong to young consumers in Izmir, in Turkey. The survey consists of three groups of questions. In the first group, a total of 52 luxury and non-luxury brand names like Bershka, Network, Vakko, Tommy Hilfiger, Koton, Massimo Dutti is given, participants are asked to select luxury brands, and then the 
following question is asked whether they bought a luxury brand or not in the last year. The second group of questions consists of measurement scales, and the third group of questions consists of demographic questions. The convenience sampling method was used, and 450 questionnaires were distributed in October 2017. 450 After eliminating incomplete surveys, 400 questionnaires were used to test developed hypotheses.

\subsection{Method and Measures}

To measure status consumption a scale with 5 items that was developed by Eastman et al. (1999), to measure self-concept clarity a scale with 12 items that was developed by Campbell et al. (1996), to measure need for uniqueness a scale with 15 items that was developed by Ruvio et al. (2007), to measure peer pressure a scale with 11 items that was developed by Santor et al. (2000), to measure social consumption motivations a scale with 4 items that was developed by Moschis and Churchill (1978) and updated by Moschis (1981), to measure attitude toward luxury products a scale with 12 items that was developed by Dubois and Laurent (1994), to measure purchase intention a scale with 4 items that were developed by Esch et al. (2006) is used.

All the scales were operationalized using multi-item five-point Likert scales (anchored at one $=$ "Strongly Disagree" to $5=$ "Strongly Agree"). Using SPSS 20.0 and AMOS 20 statistics software the data was analyzed. Descriptive statistics, confirmatory factor analysis (CFA) and structural equation modeling (SEM) were used in data analysis.

\subsection{Data Analysis, Reliability and Validity}

Structural equation modeling analysis was performed with IBM's AMOS 20.0 to test data. Firstly, the measurement model was examined using confirmatory factor analysis (CFA) followed by hypotheses. The reliability and validity of the scales used in the research were analyzed. For the reliability analysis, the study used Cronbach's alpha as the internal consistency coefficient that should be $>0.70$ (Hair et al., 1998: 118). The validity of scales was also tested by the construct validity. The construct validity refers to the degree to which a measuring instrument can legitimately measure what it claims to be measuring. The construct validity of a measure is based on convergent and discriminant validity. For convergent validity, one should be able to show a correspondence or convergence between similar structures (Bolarinwa, 2015). Construct reliability (CR) should be $>0.70$ and the average variance extracted (AVE) for each construct in a measure should be $>0.50$ to establish convergent validity (Fornell and Larcker, 1981; Hair et al., 2010). Furthermore, CR should be higher than AVE. For discriminant validity, one should be able to show a divergence between structures. To establish discriminant validity, the correlation coefficient of two constructs should be less than the square root of the AVE of each construct. Maximum Shared Variance (MSV) should also be considered to test discriminant. The results of the reliability and validity are in Table 1 .

Table 1: Validity and Reliability of Factors

\begin{tabular}{|l|l|l|l|l|l|l|l|l|l|l|l|l|}
\hline & CR & AVE & MSV & MaxR(H) & P.I & S.C & C.C & U. & A.S & Status & S.C.M & A.T.L \\
\hline P.I & 0,802 & 0,506 & 0,332 & 0,816 & 0,711 & & & & & & \\
\hline S.C & 0,777 & 0,513 & 0,082 & 0,893 & 0,241 & 0,557 & & & & & \\
\hline C.C & 0,852 & 0,593 & 0,224 & 0,937 & 0,456 & 0,254 & 0,770 & & & & & \\
\hline U.C & 0,770 & 0,536 & 0,130 & 0,950 & 0,178 & 0,287 & 0,360 & 0,732 & & & & \\
\hline A.S & 0,852 & 0,593 & 0,224 & 0,963 & 0,241 & 0,267 & 0,473 & 0,344 & 0,770 & & & \\
\hline Status & 0,798 & 0,502 & 0,332 & 0,968 & 0,576 & 0,237 & 0,252 & 0,043 & 0,073 & 0,708 & & \\
\hline S.C.M & 0,731 & 0,527 & 0,389 & 0,971 & 0,446 & 0,225 & 0,216 & 0,074 & 0,106 & 0,543 & 0,691 \\
\hline A.T.L & 0,708 & 0,518 & 0,389 & 0,973 & 0,548 & 0,229 & 0,243 & 0,141 & 0,084 & 0,571 & 0,624 & 0,598 \\
\hline
\end{tabular}

$\mathrm{P}=$ Purchase Intentions; S.C. = Self Concept Clarity; C.C= Creative Choice; U.C= Unpopular Choice; A.S. = Avoidance of Similarity; Status Consumption; S.C.M.= Social Consumption motives; A.T.L= Attitudes towards Luxury Brands 
The validity of constructs was tested by confirmatory factor analysis (CFA). Based on the results of CFA, all constructs satisfy the criteria recommended for CFA that can be seen in Table 2. (Chi-square: 704,419; df: 459; Chi-square/df: 1,53; RMSEA: 0,03; RMR: 0,09; GFI: 0,91, CFI: 0,94; AGFI: 0,89; NFI: 0,94; NNFI: 0,93 (Hair et al., 2006).

Table 2: Goodness of Fit Indices

\begin{tabular}{|c|c|c|}
\hline $\begin{array}{l}\text { Goodness-of-fit } \\
\text { index }\end{array}$ & $\begin{array}{l}\text { Acceptable fit } \\
\text { Index }\end{array}$ & Perfect fit index \\
\hline \multicolumn{3}{|l|}{ Square $\left(X^{2}\right)$} \\
\hline \multicolumn{3}{|l|}{$\begin{array}{l}\text { Degree of } \\
\text { Freedom (df) }\end{array}$} \\
\hline $\begin{array}{c}\text { Square / Degree of } \\
\text { Freedom }\left(X^{2} / d f\right)\end{array}$ & $1-5$ & $0 \leq x 2 / d f \leq 2$ \\
\hline GFI & $0.90 \leq \mathrm{GFI} \leq 0.95$ & $0.95 \leq \mathrm{GFI} \leq 1.00$ \\
\hline$A G F I$ & $0.85 \leq \mathrm{AGFI} \leq 0.90$ & $0.90 \leq \mathrm{AGFI} \leq 1.00$ \\
\hline RMSEA & $0.05 \leq \mathrm{RMSEA} \leq 0.08$ & $0 \leq \mathrm{RMSEA} \leq 0.05$ \\
\hline CFI & $0.95 \leq \mathrm{CFI} \leq 0.97$ & $0.97 \leq \mathrm{CFI} \leq 1.00$ \\
\hline$N N F I=T L I$ & $0.95 \leq \mathrm{NNFI} \leq 0.97$ & $0.97 \leq \mathrm{NNFI} \leq 1.00$ \\
\hline$N F I$ & $0.90 \leq \mathrm{NFI} \leq 0.95$ & $0.95 \leq \mathrm{NFI} \leq 1.00$ \\
\hline
\end{tabular}

\section{FINDINGS}

\subsection{Sample Description}

The median of students' age is 21 , and the mode is 20 . Around 30 percent of the students are sophomore, and almost 59 percent of the sample is female, 41 percent is male. $11 \%$ of students are working and their monthly income at most (41, $9 \%) 1001-2000 \mathrm{TL}$. Students' family income is 2001-3000 TL at most (49\%). Only $1,8 \%$ of the participants are married. Demographics can be seen in Table 3 .
Table 3: Demographics

\begin{tabular}{lll|lll} 
Education & & & $\begin{array}{l}\text { Are you } \\
\text { working? }\end{array}$ & & \\
Prep class & 39 & 9,8 & Yes & 44 & 11,0 \\
Freshman & 92 & 23,0 & No & 355 & 88,8 \\
Sophomore & 121 & 30,3 & $\begin{array}{l}\text { If yes; your } \\
\text { income? }\end{array}$ & & \\
Junior & 94 & 23,5 & 0-1000TL & 15 & 34,9 \\
Senior & 49 & 12,3 & $1001-2000 T L$ & 18 & 41,9 \\
Monthly Income (Family) & 2001-3000TL & 8 & 18,6 \\
0-1000TL & 19 & 4,8 & $4001 T L+$ & 2 & 4,7 \\
1001-2000TL & 61 & 15,3 & Gender & $\mathrm{F}$ & $\%$ \\
2001-3000TL & 256 & 64,0 & Female & 237 & 59,3 \\
3001-4000TL & 8 & 2,0 & Male & 163 & 40,8 \\
4001-5000TL & 3 &, 8 & Marital status & $\mathrm{f}$ & $\%$ \\
5001-6000TL & 2 &, 5 & Single & 393 & 98,3 \\
6001TL + & 5 & 1,3 & Married & 7 & 1,8
\end{tabular}

\subsection{Hypothesis Testing}

As mentioned before, the study aims to determine the factors that influence young consumer's purchasing intention to buy luxury brands. So testing research hypotheses, Structural Equation Modeling was used. The structural model developed in this study examines the effect of self-concept clarity, creative choice, unpopular choice, avoidance of similarity, status consumption on social consumption motives, and then attitudes towards luxury brands on purchase intention to buy luxury products. The structural model Goodness of Fit values are Chi-square: 51,293; df: 13; Chi-square/df: 3,94, RMSEA: 0.09, RMR: 0,06; GFI: 0.96, AGFI: $0.89, \mathrm{CFI}: 0,96$. According to fit indexes, all values of structural model are within the acceptable limits. The research model and SEM results are in Table 4 and Figure 2.

Table 4: The research model SEM results

\begin{tabular}{|c|c|c|c|c|c|}
\hline & Estimates & C.R. & p-value & $\mathbf{R}^{2}$ & Hypothesis \\
\hline Social Consumption Motives -Self Concept Clarity & 0,080 & 0,071 & 0,262 & \multirow[t]{5}{*}{0,228} & H3 is not accepted \\
\hline Social Consumption Motives -Creative Choice & 0,094 & 1,975 & 0,048 & & H4a is accepted \\
\hline Social Consumption Motives -Unpopular Choice & $-0,032$ & $-0,539$ & 0,590 & & H4b is not accepted \\
\hline Social Consumption Motives -Avoiding Similarity & $-0,029$ & $-0,581$ & 0,561 & & $\mathrm{H} 4 \mathrm{c}$ is not accepted \\
\hline Social Consumption Motives -Status Consumption & 0,476 & 9,086 & 0,000 & & $\mathrm{H} 1$ is accepted \\
\hline Attitude- Status Consumption & 0,377 & 8,003 & 0,000 & \multirow[t]{2}{*}{0,289} & $\mathrm{H} 2$ is accepted \\
\hline Attitude-Social Consumption Motives & 0,213 & 4,978 & 0,000 & & H5 is accepted \\
\hline Purchase Intention-Attitude & 0,858 & 8,035 & 0,000 & 0,13 & $\mathrm{H} 6$ is accepted \\
\hline
\end{tabular}




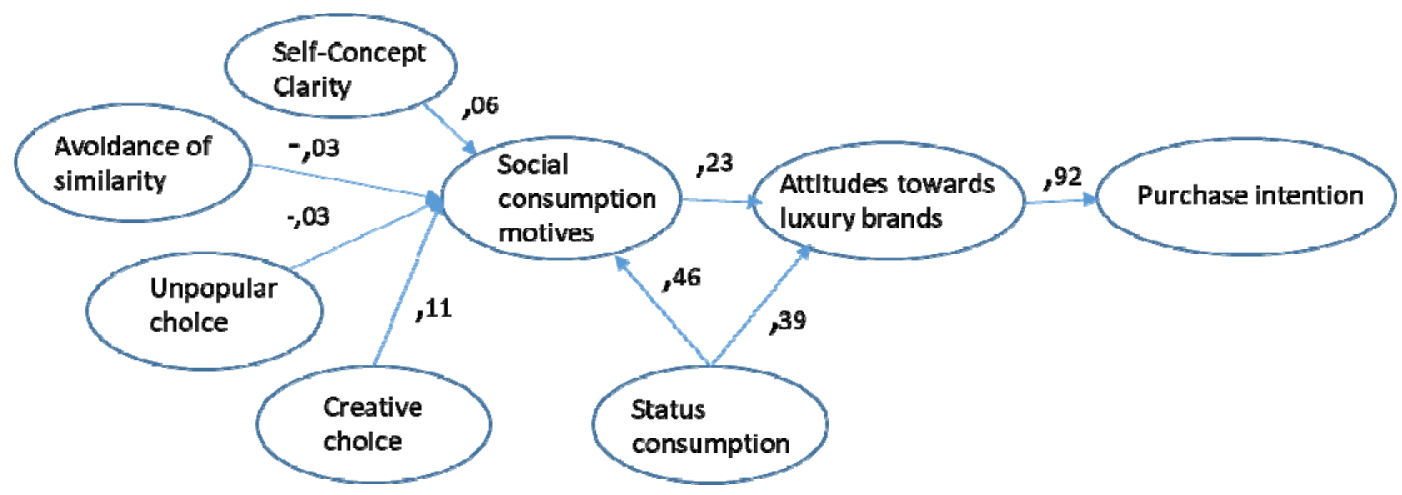

Figure 2: SEM Model

As seen in Table 4, there is a statistically significant relationship between status consumption, creative choice and the social consumption motives. Status consumption also has a positive effect on attitudes towards luxury brands. Social consumption motives affect attitudes towards luxury brands and then purchase intention of luxury brands. Consistent with the previous research (Goldsmith and Clark, 2012; Eastman and Liu, 2012; Millan and Mittal, 2017; Eastman and Eastman, 2011) this result shows that younger consumers are found to spend on status products to broadcast their self-image and social position in their social surroundings. According to the findings, self-concept clarity does not influence social consumption motives. This result is not consistent with the other studies (Alvandi et al. ,2013; Gil et al., 2012) in which it is found that there is a negative relationship between self concept clarity and social consumption motivation. One dimension of the uniqueness (creative choice) and status consumption influence the attitudes towards the luxury brand. Then it can be said that young consumers are motivated to buy a brand if the brand has a status symbol and is perceived as a creative choice. Also, socially based motives positively influence the attitudes towards luxury brands and then purchase intention to buy luxury brands.

\subsection{Analysis of the Moderating Effect of Peer Pressure}

A moderator variable is a variable that affects the strength of the relationship between a dependent and the independent variable (Hayes, 2014). The interaction variable obtained by multiplying the moderator variable and the independent variable was used to analyze the moderating effect. If the interaction variable is significant, there is a moderating effect (Hayes, 2014). The model was tested the moderating effect of peer pressure and it can be seen in Figure 3. (Goodness of Fit values of the model are Chi-square: 70,$598 ; \mathrm{df:} 19$; Chi-square/df: 3,71, RMSEA: 0.09, RMR: 0,05; GFI: 0.96, AGFI: 0.88, CFI: 0,95). According to fit indexes, all values of structural model are within the acceptable limits.

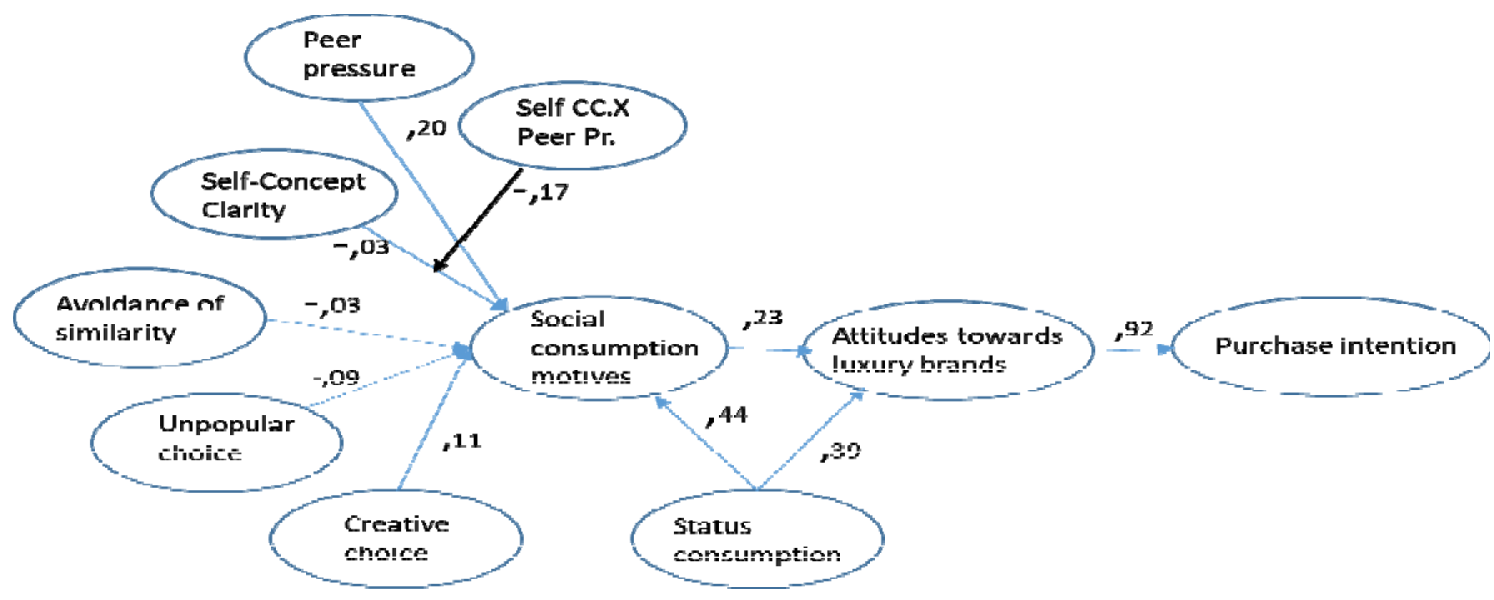

Figure 3: The Moderating Effect of Peer Pressure 
Figure 4 illustrates the moderating effect of peer pressure in the relationship between social consumption motives and self-concept clarity.

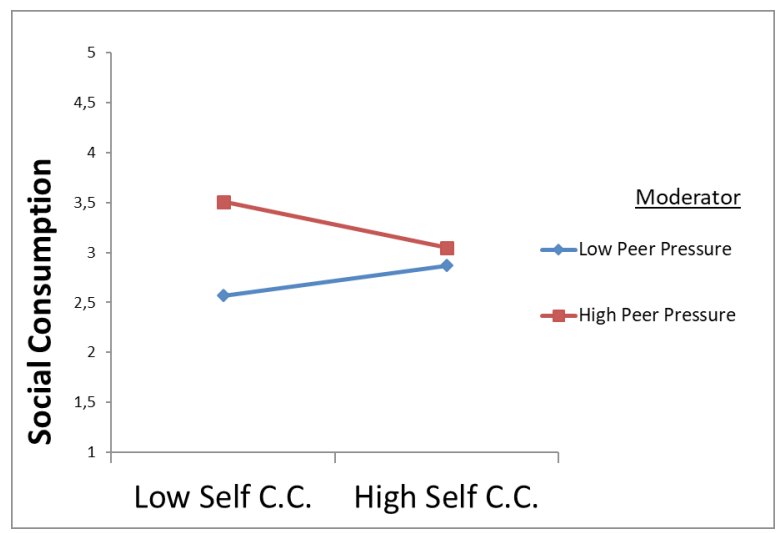

Figure 4: Illustration of the Moderating Effect of Peer Pressure

According to the Figure 4, peer pressure strengthens the negative relationship between self-concept clarity and social consumption motives. In the high peer pressure, individuals' self-concept clarity is low, and then social consumption motives are high. If young consumers feel high peer pressure from their friends, they are motivated to consume luxury brands since their self-concept clarity is low, i.e., they are not confident about themselves. On the contrary, if young consumers feel low pressure from their friends, their tendency to consume luxury brand is low because of their high self-confidence.

\subsection{Discussion and Conclusion}

This study aims to investigate the factors affect the purchase intention of luxury fashion brands. Self-concept clarity, status consumption, uniqueness, social consumption motives, and attitudes are input factors, and purchase intention is the output factor in this research. Peer pressure is the moderating factor in the relationship between self-concept clarity and social consumption motives. Findings showed that status consumption and creative choice (one dimension of the uniqueness) influence social consumption motives. Social consumption motives have a positive effect on attitudes towards luxury brands and then purchase intention to buy luxury brands. However, self-concept clarity, unpopular choice, and avoidance of similarity do not influence social consumption motives and purchase intention. Then it might be said that, if a brand is perceived as a status symbol and holds a creative image, young consumers are motivated to buy that brand for social acceptance. Socially consumption positively affects attitudes towards a luxury brand, and positive attitudes increase the purchase intention to buy the luxury brand.

According to the findings, it can be said that social and group related factors have more influence on young consumers' luxury brand preferences. Young consumers prefer luxury brands because the social groups approve them as a status symbol. According to young consumers, luxury brands have uncommon style, and this fosters them to feel creative. Also, peer pressure has a moderating effect on the relationship between self-concept clarity and social consumption motives. It is assumed that self-concept clarity has a negative influence on social consumption motivation. If a young consumer relies his/her own consciousness, he/she feels no need to consume a brand to be part of a social group.

However, if young consumers feel intense peer pressure on their brand choices, their tendency to buy a luxury brand to belong the social group was assumed too. Findings showed that peer pressure influences the relationship between self-concept clarity and social consumption motives. Also, peer pressure strengthens the negative relationship between them. The peer pressure has a positive effect on social consumption motives but if it moderates self-concept clarity and social consumption relationship, peer pressure has a negative influence on the relationship. Then it can be said that, if young consumers are confident about their self-reflection and have self-esteem, pressure from their friends does not influence their decisions on luxury brand consumption. These result are consistent with the previous studies (Brown et al. , 1986; Santor et al., 2000; Sonejia et al., 2015; Gil et al., 2017) in which it is found that peer pressure arises where an individual feel himself or herself pressured to act or think in certain ways among the others. And low SCC consumers are more influenced by the others, and peer pressure leads to consumption motivations like buying and using products or brands or to please their peers by engaging themselves with luxury brands (Gil et al., 2017; Timperio et al., 2015; Shukla, 2012; Martin, 2009; Moschis and Churchill, 1978; Gentina et al., 2016).

To sum, the social dimension of consumption influences the young consumers' preference on and intention to buy the luxury brands. Luxury brand consumption is mostly related to social environment and friends. Also, if the brand has a status image and is creative, this imaginative style plays an important role 
in young consumers' decisions. Young consumers buy a luxury brand to gain respect and acceptance from their social environment.

\subsection{Implications and Limitations}

The main contributions of this research to the literature are not only about to test social and psychological factor influences on purchase intention (social consumption motives, attitudes, feeling uniqueness, status consumption, peer pressure, and self-concept clarity) but also to investigate the moderating effect of the peer pressure. It is found that peer pressure has a positive influence on purchase intention without a moderating effect, whereas peer pressure's positive influence on social consumption motives declines with moderating effect. Then, factors' conjunct and direct effect on the output factors should be considered.

In addition to the contributions, the study offers companies various suggestions. Young consumers' attitudes towards luxury brands consist of their perceptions about the brand. If they perceive the brand as a status symbol and if the brand makes them feel different or if young consumers think that choosing the brand helps to separate them from other people regarding being creative, their purchase intention of luxury brand decreases. Young consumers want to be similar with their peers by using the luxury brand but if the brand has a creative image on the consumers. Then, luxury brand companies should focus on brand image and the style of the brand they create. Also, social consumption motives have an important role in the attitudes towards luxury brands. References groups like friends or peers should be taken into consideration by companies. To reach important reference groups, to perceive them and to become popular within youth might be a major strategy for the companies.

This paper tests the relationship between ready-to-wear luxury brand purchasing intentions, social and personal factors. Future studies can consider investigating different product categories to test factors influence on buying luxury brand intentions due to effective factors can change the product type. Luxury brand preferences are mostly under the influence of social factors but based on the findings it can be recommended that personal factors like personality traits and self-conscious can also have effects on decision making. Future research can conduct studies focusing on more personality based factors. To sum the limitations of the study, it can be said that this study surveyed only university students in Izmir and addressed only ready-to-wear luxury brands. Then the findings cannot be generalized to different product groups, and consumers who live in Turkey. 


\section{REFERENCES}

"2020'de Lüks Tüketim Pazarını X ve Y Kuşakları Yönetecek" (2016) https://odemeteknolojileri. com/2016/07/30/bain-luks-tuketim-raporu-2016/, (20.12.17)

Açıkalın, S. and Erdoğan, L. (2004) “Veblen'ci Gösteriş Amaçlı Tüketim" SÜ iiBF Sosyal ve Ekonomik Araştırmalar Dergisi, 7: 1-18.

Ajzen, I. (1991) "The Theory of Planned Behavior" Organizational Behavior and Human Decision Processes, 50: 179-211.

Akturan U., Tezcan N. and Vignolles A. (2011). "Segmenting young adults through their consumption styles: a cross-cultural study" Young Consumes, 12 (4): 348-360.

Alvandi, M., Fazli, S. and Najafi, S. (2013) "Investigating the Impact of Self on Attitudes toward Luxury Brands Among Teens in Iran" International Research Journal of Applied and Basic Sciences, 5(7): 854-865.

Amaldoss, W. and Jain, S. (2005), "Pricing of Conspicuous Goods: A Competitive Analysis of Social Effects" Journal of Marketing, Vol. 42: 30-42.

Bakewell, C. and Mitchell, V.W. (2003) "Generation Y Female Consumer Decision-Making Styles" International Journal of Retail \& Distribution Management, 31 (2), 95-106.

Barry (2017) https://apnews.com/b8fbf0d7ed86450f86cbaf71b94b92ac (29.10.17).

Belk, R. W. (2001) "Materialism and You" Journal of Research for Consumers, Issue 1 (Web-based journal). http://www.jrconsumers.com/academic_articles/ issue_1/Belk_.pdf (10.12.17).

Berthon, P., Pitt, L., Micheal, P. and Berthon, Jean P. (2009) "Aesthetics and Ephemerality: Observing and Preserving The Luxury Brand" California Management Review, 52(1): 45-65.

Bilge, H. A. (2015) "Luxury Consumption: Literature Review", Khazar Journal of Humanities and Social Sciences, 18(1): 35-55.

Bock, D. E., Eastman, J. K., McKay, B. (2014) "The Impact Of Economic Perceptions On Status Consumption: An Exploratory Study Of The Moderating Role Of Education", Journal of Consumer Marketing, (31)2: 111-117.

Bocock, Robert (1997) Tüketim. (Çev: İrem Kutluk). Ankara: Dost.

Bolarinwa, O. A. (2015) "Principles and Methods Of Validity And Reliability Testing Of Questionnaires
Used In Social And Health Science Researchers" Nigerian Postgraduate Medical Journal, 22(4): 195.

Boujbel, L. and d'Astous, A. (2015) "Exploring the Feelings and Thoughts That Accompany the Experience of Consumption Desires", Psychology and Marketing, 32 (2), 219-231.

Brown, B. B., Clasen, D. R., Eicher, S. E. (1986) "Perceptions of Peer Pressure, Peer Conformity Dispositions, and Self-Reported Behavior Among Adolescents" Journal of Personality and Social Psychology, 22: 521-530.

Bush, A.J., R. Smith, C. Martin (1999) "The Influence of Consumer Socialization Variables on Attitude toward Advertising: A Comparison of African Americans and Caucasians", Journal of Advertising, 28(3), 13-23.

Business Wire (2017a) http://www.businesswire.com/ news/home/20170825005149/en/ (29.10.17).

Business Wire (2017b) http://www.businesswire.com/ news/home/20170314006408/en/ (29.10.17).

Campbell, J. D., Trapnell, P. D., Heine, S. J., Katz, I. M., Lavallee, L. F., Lehman, D. R. (1996) "Self-Concept Clarity: Measurement, Personality Correlates, and Cultural Boundaries" Journal of Personality and Social Psychology, 70(1): 141-156.

Catry, B. (2003) "The Great Pretenders: The Magic of Luxury Goods" Business Strategy Review, 14: 10-17.

Deloitte (2017) https://www2.deloitte.com/content/ dam/Deloitte/global/Documents/consumer-industrial-products/gx-cip-global-powers-luxury-2017. pdf, (29.10.17).

Dikmen, Gözde Ö. (2008) “Lüks Marka Pazarlaması, Vertu Örneği", İstanbul Ticaret Üniversitesi Iletişim Fakültesi Dergisi, 32(1): 51-64.

Eastman, J.K., Goldsmith, R.E., Flynn, L.R. (1999) "Status Consumption in Consumer Behavior: Scale Development and Validation" Journal of Marketing Theory and Practice, 7 (3): 41-51.

Eastman, J. K. And Eastman, K. L. (2011) “Perceptions of Status Consumption and The Economy" Journal of Business \& Economics Research, 9(7): 9-20.

Eastman, J.K. and Liu, J. (2012) "The Impact of Generational Cohorts on Status Consumption: An Exploratory Look at Generational Cohort and Demographics on Status Consumption" Journal of Consumer Marketing, 2(2): 93-102.

Europlat (2017) http://www.europlat.org/global-luxury-apparels-market.htm, (29.10.17). 
Eskiler, E., Küçükibiş F. ve Soyer, F. (2016) "Genç Tüketicilerin Satın Alma Davranışları Üzerine Rol Model Etkisi: Marka Duyarlıığı Aracılık Rolü" ERPA International Congresses on Education 2016, Sarajevo / Bosnia and Herzegovina, 709-715.

Fullwood, C., James, B. M., Chen-Wilson, C.H.J. (2016) "Self-Concept Clarity and Online Self-Presentation in Adolescents" Cyberpsychology, Behavior, And Social Networking, 19(12): 1-6.

Gentina, E. G., Shrum, L. J., Lowrey, T. M., Vitell, S. J. (2016) "An Integrative Model of the Influence of Parental and Peer Support on Consumer Ethical Beliefs: The Mediating Role of Self-Esteem, Power, and Materialism" Journal of Business Ethics, pp.1-14, DOI 0.1007/s10551-016-3137-3.

Gil, L. A., Dwivedi, A., Johnson, L. W. (2017) "Effect of Popularity and Peer Pressure on Attitudes toward Luxury among Teens" Young Consumers, 1(1): 84-93.

Gil, L. A., Kwon, K. N, Good, L. K., Johnson, L. W. (2012) “Impact of Self On Attitudes Toward Luxury Brands Among Teens" Journal of Business Research, 65: 1425-1433.

Goldsmith, R.E., Clark, R.A. (2012) "Materialism, Status Consumption, and Consumer Independence" The Journal of Social Psychology, 152 (1): 43-60.

Gregorio, F., Y. Sung (2010) “Understanding Attitudes Toward and Behaviors in Response to Product Placement" Journal of Advertising, 39(1), 83-96.

Grubb E, Grathwohl H. 1967 "Consumer Self-Concepts, Symbolism and Market Behavior: A Theoretical Approach" Journal of Marketing, 31(4): 22-27.

Guerrettaz, J and Arkin, R. M. (2016) “Distinguishing the Subjective and the Objective Aspects of Self-Concept Clarity" Social and Personality Psychology Compass, 10(4): 219-230.

Hair, J. F., Anderson, R. E., Tatham, R. L., \& Black, W. C (1998) "Multivariate Data Analysis", 5th Edition,. NY: Prentice Hall International.

Hayes, J. (2014) "The Theory and Practice of Change Management", Palgrave Macmillan.

Hauck E. ve Stanforth N. (2007), "Cohort Perception of Luxury Goods and Services" Journal of Fashion Marketing and Management, 11(2): 175-188.

Henna Syrjälä, Hanna Leipämaa-Leskinen, Pirjo Laaksonen, (2015) 'Social Needs in Finnish Young Adults' Mundane Consumption" Young Consumers, Vol. 16 Issue: 3, pp.301-315.

Kapferer, J.N. (1998) "Why Are We Seduced By Luxury Brands?" The Journal of Brand Management, 6 (1): 44-9.
Kastanakis, M. N., and Balabanis, G. (2014) “Explaining Variation in Conspicuous Luxury Consumption: An Individual Differences Perspective" Journal of Business Research, 67(10), 2147-2154.

Kavak B, Giire E, Eryig C, Tekta O. (2009) “Examining The Effects Of Moral Development Level, Self-Concept, And Self Monitoring On Consumers' Ethical Attitudes" Journal of Business Ethics, 88: 115-135.

Kernis M, Paradise A, Whitaker D, Wheatman S, Goldman B. (2000) "Master Of One's Psychological Domain? Not Likely If One's Self-Esteem Is Unstable" Personality and Social Psychology Bulletin, 26 (10): 1297-1305.

Kilsheimer, J. C. (1993) "Status Consumption: The Development and Implications of a Scale Measuring the Motivation to Consume For Status" The Florida State University, Phd. Dissertation, UMI.

Kim, D. and Jang, S. (2014) "Motivational Drivers for Status Consumption: A Study of Generation Y Consumers" International Journal of Hospitality Management, 38, 39-47.

Luni, N., Charstadu, P., Ghafari, P. (2010) "Investigating Effective Factors on Customer's Behavior in Preferring Foreign Brands to Domestic Brands (A Case Study: University Students)" Journal of Management Marketing, 8: 227-254.

Lynn, M. and Harris, J. (1997) "Individual Differences In the Pursuit of Self-Uniqueness through Consumption" Journal of Applied Social Psychology, 27(21): 1861-1883.

Manikandan, K. and Rajamohan, A. (2014) "Consumer's Need for Uniqueness in Buying Small Cars" Journal of Management Policies and Practices, 2 (1), 135-146.

Makgosa, R. (2010) "The Influence of Vicarious Role Models On Purchase Intensions of Botswana Teenagers" Young Consumers, 11 (4): 307-319.

Makgosa, R. and Mohube, K. (2007) "Peer Influence on Young Adults' Products Purchase Decisions" African Journal of Business Management, 1(3): 64-71.

Martin, C. A. (2009) "Consumption Motivation and Perceptions of Malls: A Comparison of Mothers and Daughters" Journal of Marketing Theory and Practice, 17 (1): 49-61.

Martin, C. A., Turley, L.W. (2004)“Malls and Consumption Motivation: An Exploratory Examination of Older Generation Y Consumers" International Journal of Retail \& Distribution Management, 32(10): 464-475.

Millan, E. and Mittal, B. (2017) "Consumer Preference for Status Symbolism of Clothing: The Case of the 
Czech Republic" Psychology \& Marketing, 34(3): 309-322.

Miremadi, A., Fotoohi, H., Sadeh, F., Tabrizi, F., \& Javidigholipourmashhad, K. (2011) "The Possible Effects Of Need For Uniqueness's Dimensions On Luxury Brands: Case Of Iran And UAE" International Journal of Marketing Studies, 3(3), 151-160.

Mittal, B. (2015) "Self-Concept Clarity: Exploring Its Role in Consumer Behavior" Journal of Economic Psychology, 46: 98-110.

Moschis, G.P and Churchill G.A. (1978) "Consumer Socialization: A Theoretical and Empirical Analysis" Journal of Marketing Research, 15(4): 599-609.

Moschis, G. (1981) "Patterns of Consumer Learning" Journal of the Academy of Marketing Science, 9(2):110-26.

Mutlu, M. H., Çeviker, A., Çirkin, Z. (2011) "Tüketici Etnosentrizmi ve Yabancı Ürün Satın Alma Niyeti: Türkiye ve Suriye Üzerine Karşılaştırmalı Analiz" Sosyo Ekonomi, 1: 52-74.

Na, J., Chan, M. Y., Lodi-Smith, J. (2016) "Social-Class Differences In Self-Concept Clarity and Their Implications for Well-Being" Journal of Health Psychology, 1359105316643597.

Noguti, V. and Bokeyar, A. (2011) "Fantasy-Shopping, Self-Concept Clarity, and Self-Affirmation" in AP - Asia-Pacific Advances in Consumer Research Volume 9, eds. Zhihong Yi, Jing Jian Xiao, and June Cotte and Linda Price, Duluth, MN : Association for Consumer Research, Pages: 158-159.

O'Cass, A., Frost, H., (2002) "Status Brands: Examining The Effects Of Non-Product Related Brand Associations On Status And Status Consumption" Journal of Product \& Brand Management, 11 (2), 67-88.

O'Cass, A., and McEwen, H. (2005) “Exploring Consumer Status and Conspicuous Consumption" Journal of Consumer Behaviour, 4(1): 25-39.

O'Cass, A., Siahtiri, V., (2013) "In Search Of Status through Brands from Western and Asian Origins: Examining the Changing Face of Fashion Clothing Consumption in Chinese Young Adults" Journal of Retailing and Consumer Services, 20 (6), 505-515.

O'Cass, A., Lee, W. J., Siahtiri, V. (2013) "Can Islam and Status Consumption Live Together in the House of Fashion Clothing?" Journal of Fashion Marketing and Management: An International Journal, 17(4): 440-459.

O'Curry, S., Strahilevitz, M., (2001) "Probability and Mode of Acquisition Effects On Choices between
Hedonic and Utilitarian Options" Marketing Letters, 12 (1), 37-49.

Odabaşı,Y. (1999) "Tüketim Kültürü” Birinci Baskı, İstanbul: Sistem Yayıncılık.

Odabaşı, Y., Barış, G. (2002) “Tüketici Davranışı” İstanbul, Medicat Akademi.

Odabaşı, Y. (2014) “Postmodern Pazarlama” İstanbul, Media Cat.

Phau, I., Cheong, E., (2009) "How Young Adult Consumers Evaluate Diffusion Brands: Effects Of Brand Loyalty And Status Consumption" Journal of International Consumer Marketing, 21 (2), 109-123.

Rhee J, Johnson K. (2012a) "Investigating Relationship between Adolescents' Liking for an Apparel Brand and Brand Self Congruency" Young Consumers, 13 (1): 74-85.

Rhee J, Johnson K. (2012b) "Predicting Adolescents' Apparel Brand Preferences" Journal of Product \& Brand Management, 21 (4): 255-264.

Roper, S., Caruana, R., Medway, D., Murphy, P. (2013) "Constructing Luxury Brands: Exploring the Role of Consumer Discourse" European Journal of Marketing, 47(3/4): 375-400.

Ruvio, A. (2008) “Unique Like Everybody Else? The Dual Role of Consumers' Need for Uniqueness" Psychology \& Marketing, Vol. 25 No. 5, pp. 444-464.

Santor, D. A., Messervey, D., Kusumakar, V. (2000) “Measuring Peer Pressure, Popularity, and Conformity in Adolescent Boys and Girls: Predicting School Performance, Sexual Attitudes, and Substance Abuse" Journal of Youth and Adolescence, 29(2): 163-182.

Schade, M., Hegner, S., Hegner, S., Horstmann, F., \& Brinkmann, N. (2016) "The Impact of Attitude Functions On Luxury Brand Consumption: An Age-Based Group Comparison" Journal of Business Research, 69(1): 314-322.

Shavelson R, Hubner J, Stanton G. (1976) "Self-Concept: Validation of Construct Interpretations" Review of Educational Research, 46(3): 407-41.

Shukla P. (2012) "The Influence of Value Perceptions on Luxury Purchase Intentions In Developed and Emerging Markets" International Marketing Review, 29 (6): 574-596.

Solomon, M., Bamossay, G., Askgaard, S. (2002) "Consumer Behaviour - A European Perspective", Prentice Hall.

Sombart,W. (1998) “Aşk, Lüks ve Kapitalizm” Necati Aça (çev.), Ankara: Bilim ve Sanat Yayınları. 
Sonejia, D., Riedel, A., Martin, B. (2015) "How Gordon Ramsay Appeals To Consumers: Effects Of Self-Concept Clarity And Celebrity Meaning On Celebrity Endorsements" Journal of Strategic Marketing, 23(5): 457-468.

Srinivasan, R, Srivastava, R.K., Bhanot, S. (2014) "Attitudes of Young Indian Consumers towards Luxury Brands" IOSR Journal of Business and Management, 16(7): 87-97.

Stegemann, N., Denize, S. M., Miller, K. E. (2007) "Measuring Consumers Attitudes to Luxury", Proceedings of the La Londe Conference in Marketing Communications and Consumer Behavior.

The State of Fashion (2017) https://images.businessoffashion.com/site/uploads/2016/11/The_State_of_ Fashion_2017.pdf, (29.10.17).

Tenekecioğlu, B. (2005) "Pazarlama Yönetimi"Anadolu Üniversitesi Yayınları.

Tığlı, M. and Akyazgan, M. A. (2003) "Özellikli (Lüks) Tüketim Ürünlerinde Enderlik Prensibi ve Bir Uygulama" Kocaeli Üniversitesi Sosyal Bilimler Enstitüsü Dergisi, 5(1): 21-37.

Tian, K. and Bearden, W. O. (2001) "Consumers' Need for Uniqueness: Scale Development and Validation" Journal of Consumer Research, 28(1): 50-66.

Timperio, G., Tan, K.C., Fratocchi, L. and Pace, S. (2016) "The Impact of Ethnicity on Luxury Perception: The Case of Singapore's Generation Y" Asia Pacific Journal of Marketing and Logistics, 28(2), pp. 217-233

Truong, Y., McColl, R., Kitchen, P.J. (2009) “New Luxury Brand Positioning and The Emergence Of Masstige Brands" Journal of Brand Management, 16(5): 375382.
Türkiye'de Lüks Sektörü, Lüksün Yükselişi (2017) https:// www2.deloitte.com/tr/tr/pages/consumer-business/articles/global-powers-of-luxury-goods.html (20.12.17)

Tynan, C., McKechnie, S., Chhuon, C. (2010) "Co-Creating Value for Luxury Brands" Journal of Business Research, 63(11): 1156-1163.

Veblen,T. (2005) “Aylak Sınıfın Teorisi” Zeynep Gültekin ve Cumhur Atay (çev.), İstanbul: Babil Yayınları.

Vel, K. P., Captain, A., Al-Abbas, R., Al Hashemi, B. (2011) "Luxury Buying in the United Arab Emirates" Journal of Business and Behavioural Sciences, 23(3): 145-160.

Vigneron, F. and Johnson, L.W. (1999) "Measuring Perceptions of Brand Luxury" Journal of Brand Management, 11: 484-506.

Wiedmann, K-P., Hennings, N., Siebels, A. (2007) "Measuring Consumers' Luxury Value Perception: A Cross-Cultural Framework" Academy of Marketing Science Review, 11: 1-21.

Wiedmann, K. P., Hennigs, N., Siebels, A. (2009) "Value-Based Segmentation of Luxury Consumption Behavior" Psychology \& Marketing, 26 (7): 625-651.

Willett, M.,"Here's the hierarchy of luxury brands around the world" (2015), http://www.businessinsider.com/ pyramid-of-luxury-brands-2015-3, (12.12.17).

Willis, S. (1991) "Gündelik Hayat Kılavuzu" Çev: Aksu Bora ve Asuman Emre, İstanbul: Ayrıntı Yayınları.

Zayerkabeh, S. , Albabayi, A., Abdoli, M. (2012) "Studying the Effect of Brand Credibility and Brand Prestige on Brand Loyalty" Australian Journal of Basic and Applied Sciences, 6(8): 160-166. 